\title{
Anthropogenic transformation of ground beetle assemblages (Coleoptera: Carabidae) in Białowieża Forest, Poland: from primeval forests to managed woodlands of various ages
}

\author{
Jarosław J. W. Sklodowski
}

Skłodowski, J. J. W. 2006: Anthropogenic transformation of ground beetle assemblages (Coleoptera: Carabidae) in Białowieża Forest, Poland: from primeval forests to managed woodlands of various ages. — Entomol. Fennica 17: 296314.

The interference of man in the primeval forest of Białowieża (e.g. clear-cutting and reforesting fertile habitats with pine or spruce) brings about changes in carabid assemblages, including a reduction in the proportion of individuals of relict species, reduction in the mean individual biomass (MIB) and in the sum of positive characteristics (SPC; a summary indicator). Human impact in forest ecosystems causes losses of some relict species and a gain of ubiquitous species. I compared the carabid faunas of pristine forests to those of various stages of clear-cut originated succession. Clear-cutting caused a drastic decrease in MIB, a reduction in the proportion of brachypterous species, and an increase in both the number of hygrophilous species and their proportion in the assemblage.

J. Skłodowski, Department of Forest Protection and Ecology, SGGW-Warsaw Agricultural University, Nowoursynowska 159, 02-766 Warszawa, Poland; Email: sklodowski@wl.sggw.waw.pl

Received: 12 December 2005, accepted 23 April 2006

\section{Introduction}

The increasing research interest on primeval natural forests is reflected both in the number of publications (e.g., Rackham 1980, Foster et al. 1996, Assmann 1999, Bobiec et al. 2000, Bircks 2005) and in the attempts to identify and define forests resembling natural ones, at least partially. These forests are referred to as "ancient" or "recent" (Assmann 1999) or "semi-natural woodlands" (Poole et al. 2003). Białowieża Primeval Forest is the only lowland forest area in temperate Europe where large tracts of natural forests, with their typical communities, still remain (Wesołowski 1995, Bobiec et al. 2000). Perhaps surprisingly, the key to the maintenance of the naturalness was hunting by ruling families. By the fourteenth century, the forest was set aside as a royal forest, and by the sixteenth century 300 royal wardens were employed there. Their main task was to keep the forest free from unwanted intruding, illegal logging and patching (Wesołowski 2005).

Economic use of part of the Białowieża Primeval Forest began as late as the 1920's. After World War II, only about $600 \mathrm{~km}^{2}$ of the entire $1,500 \mathrm{~km}^{2}$ Białowieża Forest were left within Polish territory; the rest now belongs to Belarus. The protected zone in the Polish part of Białowieża Forest includes a national park and nature reserves, while the remaining forests are still exploited for economic purposes and exemplify a variety of types and intensities of anthropic pres- 
sure. By anthropic pressure I understand any human activity (irrespective of its temporal or spatial scale) that causes changes to an ecosystem or its constituents. These changes are often deleterious to the system. The presence of both naturally regenerated and managed forest stands in this area provides an opportunity to trace the transformation of natural woodland into managed forests that are the prevalent type of forest at present.

Anthropic pressure in timber forests may take on various forms, from construction of transportation routes and settlement areas to clear-cutting for timber production, or for creation of open areas for various other purposes. Perhaps the most profound impact is that of clear-cutting, after which local macrofaunal assemblages take several dozens of years to regenerate (Szujecki 1971, Szujecki et al. 1983, Szyszko 1983, Skłodowski 1995, 1997). As naturally regenerated forest stands are becoming managed (= timber) forests (Wesołowski 2005), the question arises whether a clear-cut originated stand can be restored (through natural re-growth or) by simply planting a new generation of trees and keeping the cutting limited in the area. To study the forest-community resilience, I used ground beetles (Carabidae) as bioindicators of environmental change.

Negative effects of clear-cutting on the macrofauna, and carabid beetles in particular, have been earlier reported by Szyszko (1983), Szujecki et al. (1983), Skłodowski (1995), Atlegrim et al. (1997), du Bus de Warnaffe and Lebrun (2004), Koivula (2001, 2002), Niemelä et al. (1993, 2003) and Pontégnie et al. (2005). These papers reveal that small- (e.g., an area of $1,600 \mathrm{~m}^{2}$ ) and large-scale clear cutting (up to tens or hundreds of ha) result in an increase in species diversity accompanied by an influx or increased abundance of species associated with open habitats and forest-habitat generalists; however, forest specialists may drastically decrease or even disappear. Atlegrim et al. (1997) pointed out that single-tree cutting did not cause such profound changes in carabid assemblages. Because smaller species often prevail in logged areas, the absence of larger species logically means a reduced mean individual biomass (MIB) of the carabid assemblage (Szyszko 1983). All the above-listed results were obtained in managed forests. However, it is less known whether the carabid fauna of primeval forests responds to logging in a similar manner.

Carabid assemblages of mature, primeval forests are characterized by a predominance of large and forest-associated species. These assemblages include relict species that may not tolerate logging (Assmann 1999). In this paper, I study the ecological effects of logging on carabids by comparing faunas of primeval forests to those obtained from clear-cut originated, regenerating (= timber, or managed) forests. The key question is to study the effect of clear-cutting on pristine forests, which is of considerable practical value for nature conservation. More precisely, I study the following hypotheses:

(1) Clear-cutting of a natural forest stand, even if limited in area, results in changes in the number of species, species composition and the structure of carabid assemblages (e.g., a statistically significant decrease in the proportion of relict and hygrophilous species and mean individual biomass);

(2) Tree re-growth of a previously clear-cut stand supports the (presumably slow) restoration of the forest ecosystem, including carabid assemblages. However, regenerated assemblages may be structurally different from the assemblages of primeval forests.

(3) I also examine whether forest type (or soil fertility) of primeval habitats has an impact on the structure and resilience of carabid assemblages.

\section{Material and methods}

\subsection{Study area and carabid sampling}

The study was part of a larger research project on the entomo-fauna of the Białowieża Primeval Forest (Szujecki et al. 2001). The study was done in the Polish part of the Białowieża Primeval Forest (northern Poland) in two stages. First, in 1999, carabid assemblages were studied in the protected parts of the Primeval Forest (Skłodowski 2003, 2005). In total, 163 plots were selected for that study. At the second stage, in 2003, 90 study plots were set up in stands subjected to different degrees of anthropic pressure. In both stages, five Barber's pitfall traps were installed at each plot 
Table 1. Studied forest habitats in Białowieża Forest and their abbreviations used in text. $\mathrm{P}=$ primeval forest; $\mathrm{C}$, MC, MD, D and DD refer to forest habitat types (see text); numbers $(5,15,40,100)$ refer to stand age (years since clear-cutting). $\mathrm{p}=$ planted pine and $\mathrm{s}=$ planted spruce monoculture; $\mathrm{C}=$ "Century" forest.

\begin{tabular}{llllll}
\hline & $\begin{array}{l}\text { Mesic } \\
\text { coniferous }\end{array}$ & $\begin{array}{l}\text { Mesic mixed } \\
\text { coniferous }\end{array}$ & $\begin{array}{l}\text { Mesic mixed } \\
\text { deciduous }\end{array}$ & $\begin{array}{l}\text { Mesic } \\
\text { deciduous }\end{array}$ & $\begin{array}{l}\text { Damp } \\
\text { deciduous }\end{array}$ \\
\hline $\begin{array}{l}\text { Primeval } \\
\text { 5-y-old plantation }\end{array}$ & P_C & P_MC & P_MD & P_D & P_DD \\
15-y-old plantation & C15 & MC5 & MD5 & - & DD5 \\
40-y-old plantation & MC15 & MD15 & - & DD15 \\
40-y-old pine monoculture & - & MC40 & MD40 & - & DD40 \\
100-y-old pine monoculture & - & - & MDp & D40p & - \\
100-y-old spruce monoculture & - & - & MD100p & D100p & - \\
Old "Century" stand & - & - & MD100s & D100s & - \\
& & - & MD_C & D_C & - \\
\hline
\end{tabular}

and serviced four times at six-week intervals, beginning on 1 May. Five traps $(0.51$ glass jar with a plastic funnel, $12 \mathrm{~cm}$ in diameter, containing 100 $\mathrm{ml} 70 \%$ ethylene glycol) were arranged $15 \mathrm{~m}$ apart along each transect. As there were $(163+90$ $=) 253$ plots, the total number of traps was 1265 in both parts of the study.

Białowieża Primeval Forest consists of a mosaic of fertile habitats that have not been subjected to the destruction and unification typical of managed forests. Two levels of forest soil humidity were selected to study: damp (wet; $70-99 \%$ of the soil surface under water during spring) and mesic (fresh; no inundation at any time of the year). Within the mesic habitat, traps were placed in four different forest stand types: coniferous (low fertility habitats with a predominance of Picea abies, Pinus sylvestris and Larix decidua), mixed coniferous, mixed deciduous, and deciduous. The latter two represent high fertility habitats with a predominance of broad-leaved tree species. In the mixed coniferous stands, coniferous tree species constituted $51-90 \%$ of all trees, whereas in the mixed deciduous stands $51-90 \%$ of the threes were broad-leaved.

The following primeval stand types were selected for investigation in the mesic habitat: coniferous (C), mixed coniferous (MC), mixed deciduous (MD) and deciduous (D); in the damp habitat, deciduous stands (DD) were included (Table 1). Each distinguished primeval forest habitat was represented by equal number of replicates (12 plots for each habitat type).

The effect of anthropic pressure on carabids was studied in analogous forest biotopes (C, MC MD, D and DD). In the C, MC, MD and DD habitats, carabid beetles were studied in 5-, 15- and 40 -years-old plantations growing in areas that had been clear-cut earlier. Additional samplings were done in MD and D habitats in 40- and 100years-old pine monocultures and 100-years-old monocultures of spruce planted in clear-cuts of previous multi-species primeval forest, and in 80 years-old stands growing in areas of large-scale clear-cutting carried out during 1927-1928 by a British company "The Century European Timber Corporation", designated here as "Century". Each variant of anthropic pressure in the study habitats $\mathrm{C}, \mathrm{MC}, \mathrm{MD}$ and $\mathrm{DD}$ was replicated three times.

\subsection{Ecological-historical types of carabid beetles}

For analytical purposes, the carabid species were divided into various groups (Table 2). The "forest relict" species group comprises species that are predominantly found in forests and reproduce there but are seldom or never observed outside closed-forest stands. Species were assigned to this group on the basis of earlier observations in Polish forests and literature (Burakowski et al. 1973, 1974, Assman 1999, Turin 2000). A high proportion of relict species in an assemblage presumably indicates the presence of little or no anthropic pressure in a given habitat.

The "brachypterous species" group used in 
Table 2. ANOVA for carabid assemblages in four forest habitats. Symbols used in pair-wise post hoc tests: $1=\mathrm{C}, 2=\mathrm{MC}, 3=$ $\mathrm{MD}, 4$ = DD, and in stands with different ages of dominant trees: $1=5-, 2=15-, 3=40$-years-old, and $4=$ (un-aged) primeval forest (see Table 1 for abbreviations).

\begin{tabular}{|c|c|c|c|c|c|}
\hline Variable & df & MS & $\mathrm{F}$ & $p$ & LSD post hoc test \\
\hline \multicolumn{6}{|c|}{ Species richness } \\
\hline Habitat & 3 & 59.347 & 6.535 & 0.001 & $1,2<3,4(p=0.001)$ \\
\hline Age & 3 & 18.407 & 2.027 & 0.118 & \\
\hline Habitat $\times$ Age & 9 & 4.938 & 0.543 & 0.837 & \\
\hline \multicolumn{6}{|l|}{ Relicts } \\
\hline Habitat & 3 & 3146.063 & 14.687 & $<0.001$ & $4<1,2<3(p<0.001) ; 2,3>1(p=0.030)$ \\
\hline Age & 3 & 1835.366 & 8.568 & $<0.001$ & $4>1,2,3(p=0.010$ to $p<0.001)$ \\
\hline Habitat $\times$ Age & 9 & 803.355 & 3.710 & $<0.001$ & \\
\hline \multicolumn{6}{|l|}{ MIB } \\
\hline Habitat & 3 & 119846.800 & 19.914 & $<0.001$ & $1<3(p<0.001) ; 4<1,2,3(p<0.001) ; 3>2(p<0.001)$ \\
\hline Age & 3 & 105229.200 & 17.486 & $<0.001$ & $4>1,2,3(p<0.001)$ \\
\hline Habitat $\times$ Age & 9 & 24089.300 & 4.003 & 0.003 & \\
\hline \multicolumn{6}{|l|}{ SPC } \\
\hline Habitat & 3 & 15574.560 & 8.743 & $<0.001$ & $4<1,2,3(p<0.001)$ \\
\hline Age & 3 & 5904.950 & 3.315 & 0.024 & $2>3(p=0.030) ; 3<4(p=0.003)$ \\
\hline Habitat $\times$ Age & 9 & 6792.380 & 3.813 & 0.001 & \\
\hline \multicolumn{6}{|l|}{ Hygrophilous } \\
\hline Habitat & 3 & 8440.183 & 34.025 & $<0.001$ & $4>1,2,3(p<0.001)$ \\
\hline Age & 3 & 1107.472 & 4.465 & 0.006 & $4<1(p=0.010) ; 4<2(p=0.003)$ \\
\hline Habitat $\times$ Age & 9 & 271.367 & 1.094 & 0.379 & \\
\hline \multicolumn{6}{|l|}{ Brachypterous } \\
\hline Habitat & 3 & 3592.541 & 16.439 & $<0.001$ & $4<1,2,3(p<0.001)$ \\
\hline Age & 3 & 709.437 & 3.246 & 0.027 & $4>3(p=0.006)$ \\
\hline Habitat $\times$ Age & 9 & 999.940 & 4.576 & $<0.001$ & \\
\hline
\end{tabular}

the analysis was distinguished on the basis of observed wing length and wing muscles. Brachypterous carabids have a low power of dispersal, which makes it difficult for them to leave the ploughed clearings quickly or to re-colonize them later on. Hence, a high proportion of brachypterous species in a community indicates an undisturbed habitat (Ribera et al. 2001).

"Hygrophilous species" were classified on the basis of earlier observations and data from Burakowski et al. $(1973,1974)$ and Turin $(2000)$. A high proportion of these species in a habitat indicates high moisture levels but may also be due to considerable shading or the presence of coarse woody debris and other factors.

The SPC index used here (see section 2.3.) was based on four different species groups: autumn breeders, large zoophages, forest species and European species (i.e., those with limited geographical ranges, compared to Palaearctic or
Holarctic species). The classification was based on observations by the author and Larsson (1939), Burakowski et al. (1973, 1974), Szyszko (1983), Szujecki et al. (1983) and Turin (2000). The reason for the inclusion of these four groups in the analyses is their predominance in carabid assemblages in mature forests: an abundance of these species indicates the recovery of the forest ecosystem (Szyszko 1983, Szujecki et al. 1983, Skłodowski 1995).

\subsection{Data analysis}

Carabid individuals were determined to species, and their body length was measured with an accuracy of $0.5 \mathrm{~mm}$. This measure was subsequently converted to biomass according to the formula proposed by Szujecki et al. (1983). The mean individual biomass (MIB) is the quotient of the sum 
of biomass of all individuals in an assemblage by their abundance (Szyszko 1983, 2002). The sum of progressive characteristics [SPC; Sklodowski (1997)] was also used. This metric is correlated with the age of the stand in question $[r=+0.93, p$ $=0.0001, n=76$; Sklodowski (1997)] and is calculated as follows:

SPC $=74.9+102 *$ LOG (stand age)

SPC is thus the sum of proportions of those groups of carabids that are dominant in mature forest stands: autumn breeders, large zoophages, forest species and European species (see section 2.2). The two values are coefficients: 74.9 for the model intercept and 102 for the regression slope.

Prior to the statistical analyses, the data were tested for normality of distributions using Shapiro-Wilk's statistic [Statistica; StatSoft, Inc. (1997)]. Species data were $\log (n) * 100$ transformed to improve normality of the distributions. Species richness was standardized to the lowest number of specimens in the samples using Simberloff's rarefaction formula (Krebs 1999).

Two-way ANOVA [Statistica; StatSoft Inc. (1997)] was used to verify the impact of clearcutting on the abundance and structure of carabid communities. Data were compared in two groups. The first comparison was among areas representing different habitat types (C, MC, MD and DD), with 12 replicates for the primeval forests and 9 replicates for each of the different types of managed (regenerating) forests. The second comparison distinguished different stand ages: 5-, 15- and 40-years-old stands (each with 12 replicates) and "indefinite" (primeval) stands (48 replicates). Equality of variances was verified using Levene's test. A post hoc comparison of significant differences in ANOVA was confirmed using the LSD (least significant difference) post hoc test. Both ANOVA comparisons were done using data with 1999 and 2003 catches pooled for each stand i.e. analyses were based on stand totals.

Species-composition similarities were compared using Ward cluster analysis based on Euclidean distances [Statistica; StatSoft Inc. (1997)]. To study the distinctiveness of carabid assemblages of the compared habitat types and stand ages, Detrended Correspondence Analysis (DCA) was carried out using CANOCO software (ter Braak \& Smilauer 1997-1999).

The hypothesis of slow regeneration of carabid fauna in regenerated forest stands was tested using two-way ANOVA [Statistica; StatSoft Inc. (1997)]. The comparison was carried out in two habitat types: MD and D (both with 24 replicates) in 40- and 100-years-old pine and spruce stands and in 80-years-old regenerated broad-leaved stands. Equality of variances was verified using Levene's test. A post hoc comparison of significant differences in ANOVA was confirmed using the LSD (least significant difference) test. The age variants of regenerated stands (40-, 80- and 100 -years-old) involved in the slow-regeneration hypothesis were included in Ward analysis of species similarity and DCA gradient analysis. Similarly, I studied whether the structure and abundance of carabid assemblages depends on the fertility of the primeval habitats subject to anthropic pressure.

\section{Results}

The first stage of the study (year 1999) yielded nearly 60,000 carabid individuals representing 105 species, with a further ca. 30,000 individuals and additional 25 species captured during the second stage (year 2003). Thus, the total number of species was 130 , accounting for one-fourth of all carabid species ever recorded within the boundaries of Poland since World War II (Burakowski et al. 1973). 50,235 individuals representing 109 species were analysed.

\subsection{Effect of clear-cutting on the abundance and structure of carabid assemblages.}

Significant differences between characteristics of carabid assemblages from primeval forests vs. those from young, regenerating (5-, 15- and 40years-old) stands were found (Tables 2-3). However, ANOVA did not indicate differences in species richness between primeval and regenerating stands, although it showed differences in percentages of relict and hygrophilous species and in the values of the SPC and MIB indices (Tables 2-3).

Percentages of relict carabids varied from $15.8 \%, 36.7 \%, 44.0 \%$ and $53.2 \%$ (mean $38.0 \%$ ) 
Fig. 1. DCA for the carabid catches presented in Appendix. See Table 1 for abbreviations of habitat codes; species are shown using abbreviations (compare Appendix for full names).

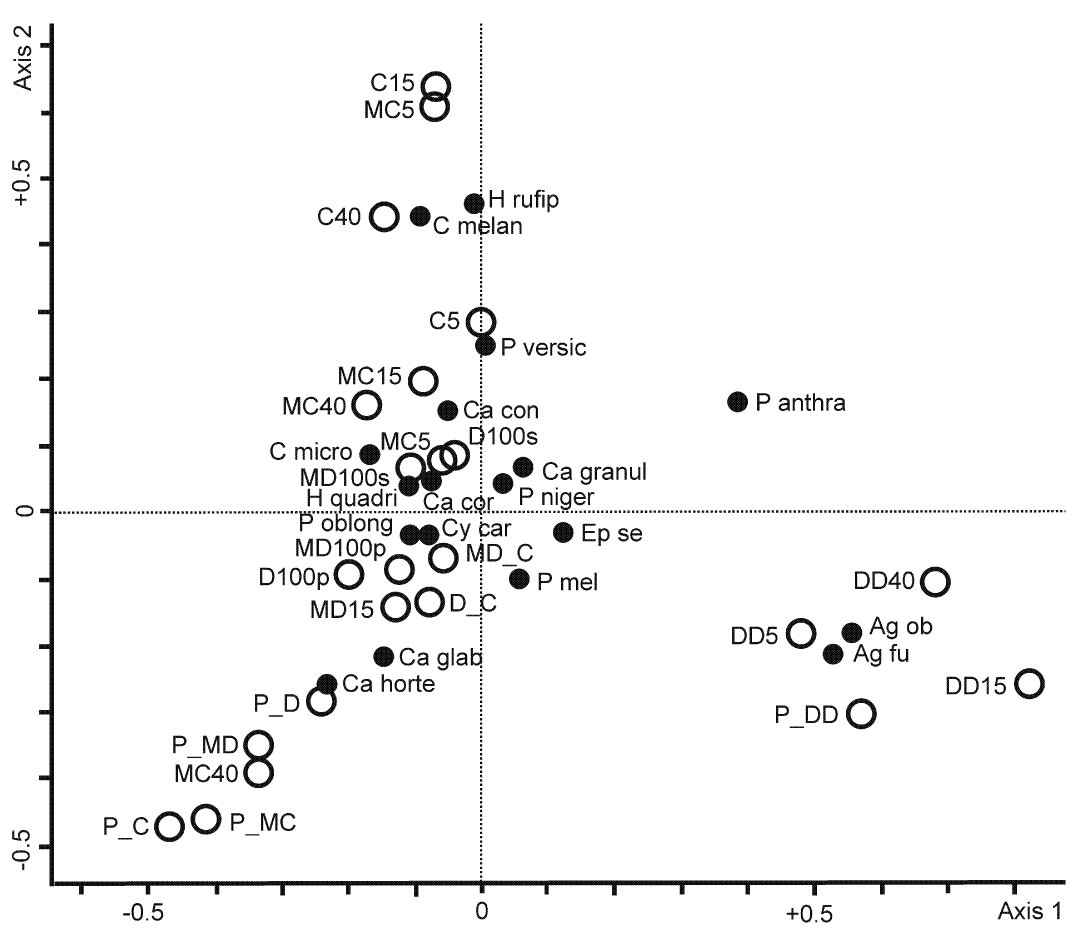

in the assemblages inhabiting the primeval habitats of DD, C, MD and MC types to $6.1 \%, 9.7 \%$ and $17.4 \%$ (mean $9.9 \%$ ) in the assemblages of 5years-old plantations of C (LSD test, $p=0.006$ ), MC (LSD test, $p=0.001)$ and MD (LSD test, $p=$ 0.01 ). Thus, relict species had apparently exhibited a definite group response to human activity. In the assemblages of the restored habitats, two rare relict species, Carabus intricatus and Leistus piceus, were not found. However, the 5-years-old plantations supported species not found in primeval stands: $C$. melanocephalus (dominance indices $15 \%$ in $\mathrm{MC}$ habitat, $5 \%$ in $\mathrm{C}$ and $4 \%$ in MD), P. caerulescens (12\% in MC and $9.6 \%$ in MD). At the same time, large forest species were absent from these plantations. On the other hand, these species had high dominance indices in the primeval forests: $C$. glabratus $8 \%$ in $\mathrm{MC}, C$. arcensis $42.6 \%$ in $C$, where also $C$. hortensis had a value of $35.6 \%$ (vs. $1.6 \%$ in the 5 -years-old plantations; Chi-square statistic $=8.37, p=0.004$ ).

DCA grouped the studied habitats along a gradient of anthropic pressure parallel to the vertical axis (Fig. 1). The four mesic habitats of primeval forest (C, MC, MD and D) scattered close to each other to the bottom-left. Anthropic pres- sure in the forest areas, resulting from clear-cutting, was followed by forest regeneration, with replacement of formerly dominant deciduous tree species by coniferous trees. Such changes are reflected in Fig. 1 by the displacement of the reference points relative to positions of the points for the primeval forest assemblages. The scores of the damp forest habitats formed a separate cluster to the right from the other habitats, suggesting a vertical course of a moisture gradient. This finding is compatible with the results of an earlier DCA for gradients of fertility and moisture, carried out for carabids collected from the primeval forest habitats only (J. W. Sklodowski, unpubl. data). Cluster analysis also indicated faunal differences between the primeval and regenerating stands. The carabids from the primeval stands (D, $\mathrm{MD}$ and $\mathrm{MC}$ ) were grouped into a distinctive agglomeration (Fig. 2).

In the assemblages inhabiting the 5- and 15years-old plantations, the proportion of hygrophilous species was significantly higher than in the assemblages from primeval stands (Table 2); for example, $47.7 \%$ vs. $13.4 \%$ in C, $26.1 \%$ vs. $19.7 \%$ in $\mathrm{MC}$ and $22.8 \%$ vs. $16.4 \%$ in MD (LSD test; $p$ for pair-wise differences varied between 


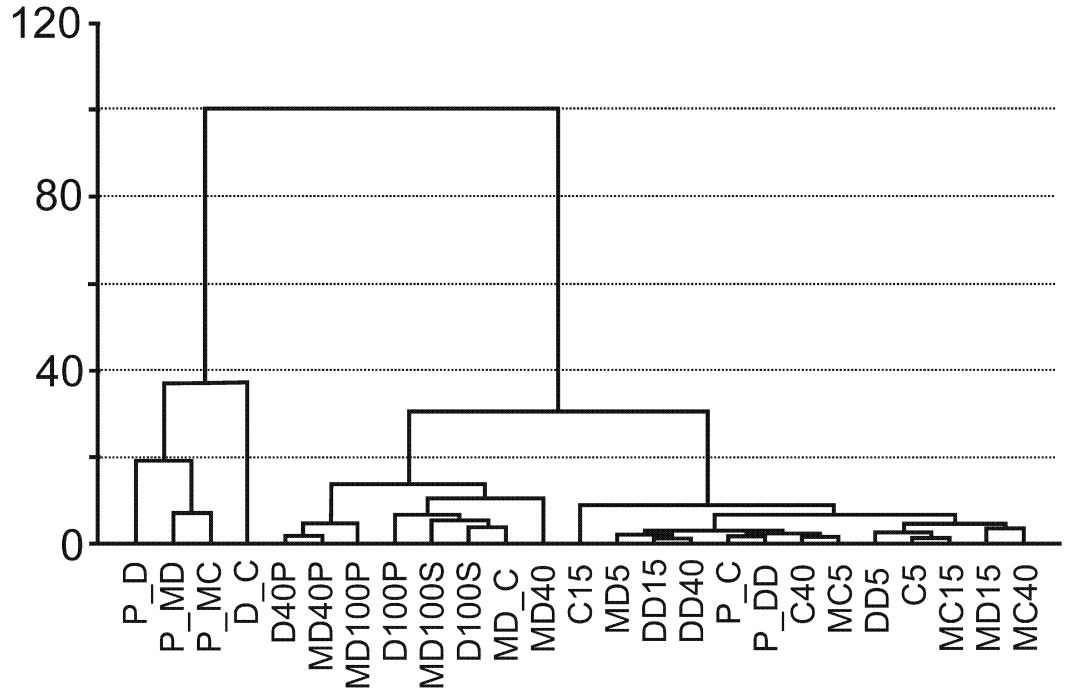

Fig. 2. Cluster analysis for the carabid catches from primeval and managed forests at the Białowieża area. Compare Table 1 for habitat codes.
0.040 and 0.001 ). Also the mean percentages of hygrophilous species in assemblages of the 40years-old plantations and the primeval stands differed markedly (Table 2).

The proportion of brachypterous species was higher in the primeval stands compared to their baseline (= mean value for each habitat separately) proportion: in $\mathrm{C}$ habitat, from a baseline of $87.2 \%$ to $76.3 \%$ in the 5 -years-old plantations and to $53.4 \%$ in the 15 -years-old plantations (LSD test, $p=0.002$ ), in MC habitat from a baseline of $81.1 \%$ to $44.1 \%$ in the 5 -years-old plantations (LSD test, $p=0.002$ ), in MD habitat from a baseline of $69.9 \%$ to $57.8 \%(F=6.670, p$ $<0.001)$. The primeval stands hosted higher proportions of brachypterous species than did 5years-old plantations. In the marshy DD habitats, on the other hand, clear-cutting increased the proportion of brachypterous individuals from $29 \%$ to $52 \%$ (LSD test, $p=0.014$ ). In the 40 -years-old plantations, the proportion of this group decreased to $22.3 \%$, corresponding to its reference in the primeval stands.

ANOVA for the mean individual biomass (MIB) and the SPC index (Table 2) revealed a significant discrepancy of the community indices between the primeval habitats [with the highest MIB values (293 mg/individual) and SPC (246.8)] and the 5-years-old plantations (with the lowest MIB values 160.6; LSD test, $p=0.0001$ ) and the 40-years-old plantations [with the lowest SPC values (232); LSD test; $p=0.034$ ].

\subsection{Resilience of carabid fauna in the regenerated stands}

The numbers of carabid species (rarefaction standardized) in the 80-years-old Century stands exceeded the species numbers of 100 -years-old pine and spruce plantations (Table 3). In the MD habitat, the mean species richness of 80-years-old Century stands was significantly higher than in the assemblages from primeval stands: 9.57 vs. 6.2 (LSD test, $p=0.008$ ). No significant differences in species richness were found between the primeval and others stands.

In the assemblages inhabiting the 40-, 80- and 100-years-old stands, the proportion of relict species was significantly lower than in the assemblages from primeval stands (from $8.3 \%$ to $16 \%$ vs. $35.7 \%$; LSD test, $p<0.0001$ ). Percentages of brachypterous carabids varied widely across the regenerated and primeval habitats, e.g., $78.3 \%$ and $78.4 \%$ in the assemblages inhabiting 40 - and 100 -years-old pine stands on MD habitats to $55.3 \%$ in the assemblages of primeval forest. The primeval stands hosted lower proportions of brachypterous species than did monocultures of pine and spruce growing in the fertile habitats of MD and $\mathrm{D}$.

In assemblages inhabiting younger (40-yearsold) stands, the proportion of hygrophilous species was significantly higher than in the assemblages from older (80-years-old) stands $(51.0 \%$ vs. $24.3 \%$; LSD test, $p<0.001)$ and in the prime- 
Table 3. ANOVA for carabid assemblages in two fertile forest habitats. Symbols used in pair-wise post hoc tests: $1=M D, 2=$ $\mathrm{MC}$, and in stands with different ages of dominant trees: $1=40-, 2=80-, 3=100$-years-old, and $4=$ (un-aged) primeval forest (see Table 1 for abbreviations).

\begin{tabular}{|c|c|c|c|c|c|}
\hline Variable & df & MS & $\mathrm{F}$ & $p$ & LSD post hoc test \\
\hline \multicolumn{6}{|c|}{ Species richness } \\
\hline Habitat & 1 & 1.176 & 0.103 & 0.750 & \multirow{3}{*}{$1<2(p=0.007) ; 3<2(p=0,037)$} \\
\hline Age & 3 & 31.980 & 2.798 & 0.050 & \\
\hline Habitat $\times$ Age & 3 & 21.532 & 1.884 & 0.147 & \\
\hline \multicolumn{6}{|l|}{ Relicts } \\
\hline Habitat & 1 & 9.849 & 0.094 & 0.760 & \multirow{3}{*}{$4>1,2,3(p<0.001)$} \\
\hline Age & 3 & 2352.114 & 21.546 & $<0.001$ & \\
\hline Habitat $\times$ Age & 3 & 495.497 & 4.749 & 0.006 & \\
\hline \multicolumn{6}{|l|}{ MIB } \\
\hline Habitat & 1 & 10017.000 & 0.895 & 0.350 & \multirow{3}{*}{$4>1,2,3(p<0.001)$} \\
\hline Age & 3 & 118475.200 & 10.584 & $<0.001$ & \\
\hline Habitat $\times$ Age & 3 & 25398.900 & 2.269 & 0.094 & \\
\hline \multicolumn{6}{|l|}{$S P C$} \\
\hline Habitat & 1 & 334.098 & 0.277 & 0.601 & \multirow{3}{*}{$1>2(p=0.008) ; 1>3(p=0.015) ; 1>4(p=0.003)$} \\
\hline Age & 3 & 6280.280 & 5.213 & 0.004 & \\
\hline Habitat $\times$ Age & 3 & 1086.107 & 0.902 & 0.448 & \\
\hline \multicolumn{6}{|l|}{ Hygrophilous } \\
\hline Habitat & 1 & 933.267 & 1.639 & 0.207 & \multirow{3}{*}{$1>2,4(p=0.001) ; 1>3(p=0.010) ; 2,3>4(p=0.001)$} \\
\hline Age & 3 & 3019.507 & 5.303 & 0.003 & \\
\hline Habitat $\times$ Age & 3 & 948.384 & 1.666 & 0.189 & \\
\hline \multicolumn{6}{|l|}{ Brachypterous } \\
\hline Habitat & 1 & 347.705 & 0.694 & 0.409 & \multirow{3}{*}{$1>2(p<0.001) ; 1>4(p=0.030) ; 2<4(p=0.007)$} \\
\hline Age & 3 & 1826.846 & 3.649 & 0.020 & \\
\hline Habitat $\times$ Age & 3 & 91.362 & 0.183 & 0.908 & \\
\hline
\end{tabular}

val stands $(51.0 \%$ vs. $15.6 \%$; LSD test, $p=$ $<0.001)$. Also, in the assemblages inhabiting the 100 -years-old stands, the proportion of hygrophilous species was significantly higher than in the assemblages from primeval forests (LSD test, $p<0.001)$. The proportion of brachypterous species was also lower in the primeval than in the 40 years-old stands ( $63.2 \%$ vs. $77.8 \%$; LSD test, $p=$ $0.03)$. ANOVA for the MIB revealed a significant discrepancy of the community indices between the primeval habitats $(297.8 \mathrm{mg} /$ individual) and the 40-, 80- or 100-years-old stands (227.9 [LSD test; $p=0.027$ ], $169.2[p<0.001]$, 231.8 [ $p=0.007]$, respectively).

\subsection{Effect of soil fertility on forest carabid assemblages.}

The numbers of carabid species (rarefaction standardized) in fertile primeval D and DD (9.2 and
9.7) stands exceeded the species richness of poorer primeval $\mathrm{C}$ and $\mathrm{MC}$ stands (6.0 and 7.4; LSD test, $p<0.001$; Table 2 ). The proportions of relict species in the carabid assemblages of the primeval DD habitats was significantly lower than in the primeval $\mathrm{C}, \mathrm{MC}$ and $\mathrm{MD}$ habitats ( $15.8 \%$ vs. $36.7 \%, 53.2 \%$ and $44.0 \%$, respectively; LSD test, $p<0.0001$ ). Also the proportion of relict species was higher in the primeval assemblages of fertile MC and MD habitats compared to their proportion in poorer primeval habitat C $(53.2 \%$ and $44.0 \%$ vs. $36.7 \%$; LSD test, $p=$ 0.001 and 0.03 , respectively).

The proportion of brachypterous species was also lower in the primeval stands DD compared to their proportion in the primeval stands of C, MC and MD (37.4\% vs. $70.6 \%, 63.3 \%$ and $69.3 \%$; LSD test, $p<0.0001$ )

ANOVA for MIB (Table 2) revealed significant differences in the community indices be- 
Table 4. Dominant and co-dominant species, with dominance indices $>5 \%$, in selected MMC and MMD habitats. For column names, see Table 1.

\begin{tabular}{|c|c|c|c|c|c|c|c|c|c|}
\hline Species & P_MD & MD5 & MD40 & MD100p & MD100s & MD_C & P_MC & MC5 & MC40 \\
\hline C. hortensis & 46.8 & - & 28.2 & 10.0 & 5.0 & - & 43.3 & 7.2 & \\
\hline P. oblongopunctatus & 18.6 & - & 17.4 & 13.8 & 34.2 & 18.5 & 10.2 & - & 21.8 \\
\hline C. glabratus & 11.1 & 7.9 & 15.8 & - & - & - & 13.3 & - & \\
\hline$P$. niger & 10.5 & 17.7 & 11.4 & 46.0 & 27.5 & 33.0 & 6.7 & 21.1 & 20.6 \\
\hline C. arcensis & 6.5 & 5.5 & 9.0 & 5.4 & - & - & 13.2 & - & 10.1 \\
\hline E. secalis & - & 12.1 & - & - & - & - & - & - & \\
\hline P. versicolor & - & 9.6 & - & - & - & - & - & 11.9 & \\
\hline H. quadripunctatus & - & 5.1 & - & - & - & - & - & - & \\
\hline C. caraboides & - & - & - & 5.4 & - & - & - & - & \\
\hline C. granulatus & - & - & - & - & 7.0 & - & - & - & \\
\hline P. melanarius & - & - & - & - & 6.1 & 23.0 & - & - & \\
\hline C. nemoralis & - & - & - & - & - & 6.4 & - & - & \\
\hline C. melanocephalus & - & - & - & - & - & - & - & 15.5 & 15.6 \\
\hline H. rufipes & - & - & - & - & - & - & - & 7.7 & \\
\hline
\end{tabular}

tween fertile primeval MD habitats (with the highest MIB $303.1 \mathrm{mg} /$ individual) and other primeval habitats: $\mathrm{MC}$ (218.3), $\mathrm{C}(178.0)$ and DD (86.6) (LSD test, $p<0.001$ ). On the other hand, in the assemblages inhabiting damp primeval habitats of the type DD, the SPC index was significantly lower than in the assemblages from others primeval stands of types C, MC and MD (184.3 vs. 236.1, 242.0 and 260.0, respectively; LSD test, $p<0.001$ ).

\section{Discussion}

\subsection{Carabid assemblage variation among the compared forest habitats}

Cluster analysis indicated faunal differences between primeval and regenerating stands (Fig. 2). The carabid samples from the primeval stands were grouped into separate agglomerations. One included the assemblages inhabiting the fertile MC, MD and D habitats of the primeval stands. However, the D primeval habitat assemblage appear located among the regenerated stands sampled within the "Century" area that otherwise formed a distinct cluster of samples. The other group, consisting of the assemblages of the poor $\mathrm{C}$ habitat and the marshy DD habitat, shared a branch together with the young 5- to 40-years-old plantations. The carabid assemblages in the 40- and 100-years-old pine and spruce monocultures also formed a separate agglomeration, which can be attributed both to the considerable shading of the litter and the reduction of its composition to one component, viz. pine or spruce needles. Such litter decomposes more slowly than mixed litter. The resulting thickness was about $10 \mathrm{~cm}$, probably supporting e.g. Pterostichus niger and P. melanarius (Table 4).

Also DCA separated the assemblages from the primeval stands of two areas on the diagram at various levels of moisture (Fig. 1). The horizontal axis could be related to an altitude gradient. However, the arrangement of all assemblages suggested a gradient of anthropic pressure increasing upward along the vertical axis, as the scores of the assemblages of the youngest plantations were located at the top. Considering also the number of carabid species disappearing from the primeval stands while harvesting, and the number of alien species that colonize new plantations on clearcuts, the result is one of profound changes in the ecosystem.

\subsection{Effect of clear-cutting and litter quality on carabid assemblages}

Niemelä et al. (1993) distinguished three general carabid responses to logging: (1) an increase in abundance of species characteristic of dry and 
open conditions; (2) an initial decrease of forest generalist species that reestablish with forest regeneration; and (3) canopy closure and disappearance of some forest specialists which seem unable to re-establish populations in cut-over stands (but see Spence et al. 1996).

In carabid assemblages of clear-cuts, forest specialists are apparently replaced by non-forest (e.g., Amara and Harpalus) species, resulting in a local increase in species diversity (Beaudry et al. 1997). Open habitat carabids, for example, are efficient in colonizing clear-cuts: the first individuals may colonize small $(<0.5 \mathrm{ha})$ clear-cut openings within months (Koivula \& Niemelä 2003). Contrary to these findings, the present study showed no change in the mean number of species following clear-cutting. However, I found few non-forest species $[P$. versicolor, $E$. secalis (MD), C. melanocephalus and H. rufipes (MC)] in the group of co-dominants in the carabid assemblages of the 5-years-old plantations. In the 15- and 40-years-old plantations, these species had apparently been replaced by the forest specialists $C$. hortensis, C. glabratus and P. oblongopunctatus (Table 4 ).

The forest generalist Pterostichus niger was a dominant species in the 5-years-old plantations. However, it has also been reported as being a dominant species in 40-years-old and older managed stands (Szyszko 1983, Sklodowski 1995). Its locomotor ability resembles those of the flightless $C$. hortensis and $C$. glabratus that were present in low numbers in the regenerating clearcuts. Studies of movement patterns of $C$. hortensis and $C$. glabratus have indicated that these species do not enter open areas (Sklodowski 1999, 2002, Assmann \& Günther 2000). Furthermore, $C$. hortensis is associated with humic soils and $C$. glabratus with abundant mosses (Niemelä et al. 1996). Also forest litter is important for carabid beetles: litter thickness and composition stimulate the occurrence of forest-associated carabids (Guillemain et al. 1997, Koivula et al. 1999, Koivula 2001, Magura et al. 2001, Koivula \& Niemelä 2003). Baguette (1993) associated the occurrence of $P$. oblongopunctatus with the "moder" type of litter, a forest floor type in which there is a distinct litter and decomposing layer and humus layer that gradually changes into, and is partly mixed with, the underlying mineral soil
(Kimmins 1997). However, according to $\mathrm{Ba}-$ guette (1993), P. niger and P. melanarius are associated with thick litter covering humic soils. Similar micro-habitat associations with litter have been observed for $C$. hortensis (Turin 2000).

The above explains why the destruction of litter and mosses during top-soil preparation in clear-cuts has negative effects on the abundance of e.g. C. hortensis and C. glabratus, while it may not affect the colonization of clear-cuts by $P$. niger, as shown in a recent capture-recapture experiment (Skłodowski 2002). This difference probably accounts for the dominance of the latter species in carabid assemblages in the 5-years-old plantations in Białowieża.

In spite of the lack of litter, $P$. niger was dominant in the carabid assemblages of 5-years-old plantations, whereas the eurytopic $P$. melanarius, relatively similar in terms of body size and diet, was not numerous there. Perhaps the more flattened body of $P$. niger allows it to easily penetrate micro-crevices in furrows created by ploughing. The slightly stockier Pterostichus melanarius was a co-dominant in the carabid assemblages of mature stands planted in the "Century" area and in the pine and spruce monocultures. Because this species was recorded only in very low abundance in the primeval stands, the higher abundance in regenerating areas apparently serves as an indicator of stand disturbance. However, Poole et al. (2003) found $P$. melanarius more abundantly in semi-natural but "mature" oak woodland than in oak plantations.

\subsection{Relict and brachypterous carabids, and clear-cutting}

However, perhaps a more important indicator of destruction of primeval stands is the depletion of relict species (Assmann 1999). In this study, the proportion of the ten relict forest species decreased in Białowieża Forest from $85 \%$ to $25 \%$ along with increasing anthropic pressure. Clearcutting, even if not particularly intense in terms of area covered, leads to the disappearance of species characteristic of older stands, such as $L$. piceus, C. intricatus and C. glabratus. In order to complete their life cycle, these species need a 
well-developed humic litter layer that is often destroyed by clear-cutting. The extensive areas subjected to the large-scale clear-cutting by the "Century" 80 years ago are still deficient in these species. Clearly, clear-cutting leads to the destruction of forest micro-habitats, the importance of which has previously been pointed out e.g. by Niemelä et al. (1996).

Clear-cutting of primeval stands in mesic habitats also decreases the proportion of brachypterous species giving way to macropterous and wing-dimorphic species in carabid assemblages. In the damp habitats, the proportion of brachypterous species increased following a clear-cut, which can be attributed to inundation of the habitat. Brachypterous species may find it difficult to escape from a flooded habitat devoid of trees that used to act as natural transpiration "pumps" during the spring floods.

Kotze \& O'Hara (2003) suggested that wingdimorphic species may survive better in highly altered environments than do brachypterous species. In my study, however, individuals of wingdimorphic species did not achieve higher dominance values than did brachypterous individuals, which may suggest that clear-cutting had no significant effects on the latter as a group. Still, the documented over $50 \%$ reduction in MIB (390 $\mathrm{mg}$ /individual vs. $160 \mathrm{mg} /$ individual) and $20 \%$ decrease in SPC (293 vs. 232) indicate profound changes. Another sign of change in the studied carabid assemblages and in the habitats was the increased proportion of hygrophilous species in the carabid assemblages of the 5-years-old plantations. This change should be ascribed to the felling of trees that had earlier removed water from the otherwise rather moist soil in Białowieża. Removal of the trees may increase habitat moisture, and consequently hygrophilous species seize this opportunity. However, eventually the subsequent growth of trees leads to restoration of the waterlevel adjusting system of trees and a gradual reduction of this group of species.

\subsection{Effect of fertility of forest habitat on carabid assemblages}

The structure of carabid assemblages appeared to be related to habitat fertility. The carabid species richness was higher in the fertile habitats $\mathrm{MC}$ and MD (7.4 and 9.2, respectively) than in the poor habitat C (6.0). The MIB and SPC, which reflect the successional phase of the assemblages, were also higher in the fertile habitats $\mathrm{MC}$ and $\mathrm{MD}$ (MIB: $218 \mathrm{mg} /$ individual and $303 \mathrm{mg} /$ individual; SPC: 242 and 260, respectively), compared to the poor habitat C (MIB: 178; SPC: 236). The fertile but water-logged DD stands had high mean species richness (9.7), coupled with low MIB (87) and SPC (184), and these also supported brachypterous species that are apparently not resistant to disturbances (Szyszko 1990, Ribera et al. 2001). The differences between these indices suggest an improvement in the quality of carabid assemblages with increasing fertility. Here, the term "quality" should be understood as referring to carabid assemblages of very old forests, with high MIB and SPC values and high proportions of brachypterous and relict species. For this reason, the degree of deterioration of an assemblage following clear-cutting is related to the degree of organization of the assemblage prior to this disturbance (Szyszko 1990).

\subsection{Conclusions: restoration of carabid fauna in regenerating stands}

Restoration of carabid fauna in managed stands may take up to 80 or 100 years (Szyszko 1983, Skłodowski 1995). There are two plans of regeneration of the ecosystem: regeneration of the litter-soil habitat and vertical growth of the forest stand. The regeneration process of the carabid fauna was documented by comparing the faunas of 40-, 80- and 100-years-old stands. This process clearly included (1) a slight gradual increase in MIB from 227 to $231 \mathrm{mg}$ /individual (vs. 298 in primeval habitats), (2) an increase in the proportion of hygrophilous species to $24 \%$ in the 80 years-old stands (compared to $15 \%$ in primeval habitats), (3) a persistent, reduced proportion of relict species, and (4) a long-persisting elevated species richness (e.g., 9.6 in 80 -years-old stands vs. 6.2 in primeval forests). As is evident from the above comparison between 80 -years-old and primeval stands, the regeneration of carabid assemblages after clear-cutting is a very slow process. The absence of the forest relict species $C$. 


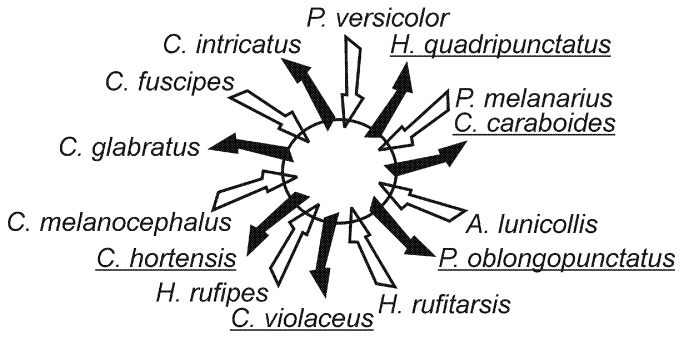

\begin{tabular}{ccc}
\hline No. lost species & Habitat type & No. added species \\
\hline 23 & 5 -y-old (C, MC) & 15 \\
17 & 5 -y-old (MD, D) & 18 \\
5 & $100-y$-old pine (MD, D) & 27 \\
5 & $100-y$-old spruce (MD, D) & 30 \\
7 & old "Century" stand (MD) & 24 \\
7 & old "Century" stand (D) & 30 \\
\hline
\end{tabular}

Fig. 3. The "snowball" effect. While harvesting, relict species (black arrows) are being replaced by ubiquitous species (white arrows). The underlined species may return to the logged areas after a reforestation and/or some decades of forest re-growth.

glabratus from the 100-years-old stands, for example, appears to indicate incomplete regeneration of the carabid assemblages there.

These changes are accompanied by a replacement process where relict forms, particularly rare ones, seem to be permanently lost to the habitat. They may return to the biocoenosis being restored but not until the first hundred post-disturbance years have passed. The effects of anthropic pressure have been compared to a snowball that loses some of the snow (here, relict species) as it rolls, while at the same time new snow (here, ubiquitous species) sticks to it (Witkowski 2000; see also Fig. 3). All these findings point to profound changes in carabid assemblages following a drastic human-caused alteration of pristine forest environment. That is why primeval forests should be subject to strict protection with any human interference reduced to a minimum.

Acknowledgements. My heartiest thanks go to Prof. A. Szujecki, the leader of our research project. I also thank the fellow workers from my department for field assistance. I also thank the Ministry of Scientific Research and Information Technology (project number J PO6L 01724 ) for financial support. I would like to thank Matti Koivula, George E. Ball and Ola Atlegrim for their help in improving the manuscript, especially for their comments and linguistic revisions of the text. I would like to thank Matti also for his friendly big help during preparation of the final version of this paper.

\section{References}

Assmann, T. 1999: The ground beetle fauna of ancient and recent woodlands in the lowlands of north-west Germany (Coleoptera, Carabidae). - Biodiversity and Conservation 8: 1499-1517.

Assmann, T. \& Günther, J. M. 2000: Relict populations in ancient woodlands: genetic differentiation, variability and power of dispersal of Carabus glabratus (Coleoptera, Carabidae) in north-western Germany. - In: Brandmayr et al. (eds.), Natural history and applied ecology of carabid beetles: 197-206. Pensoft. 304 pp.

Atlegrim, O. Sjöberg, K. \& Ball, J. P. 1997: Forestry effects on a boreal ground beetle community in spring: selective logging and clear-cutting compared. Entomologica Fennica 8:19-26.

Baguette, M. 1993: Habitat selection of carabid beetles in deciduous woodlands of southern Belgium. - Pedobiologia 37: 365-378.

Beaudry, S., Duchesne, L. \& Côté, B. 1997: Short-term effects of three forestry practices on carabids assemblages in a jack pine forest. - Canadian Journal of Forest Research 27: 2065-2071.

Bircks, H. J. B. 2005: Mind the gap: how open were European primeval forests? - Trends in Ecology and Evolution. 20: 154-156.

Bobiec, A., Burt, H., Meijr, K., Zuyderduyn, C., Haga, J. \& Vlaanderen, B. 2000: Rich deciduous forest in Białowieża as a dynamic mosaic of developmental phases: premises for nature conservation and restoration management. - Forest Ecology and Management 130: 159-175.

Burakowski, B., Mroczkowski, M., \& Stefanska, J. 19731974: Katalog Fauny Polski, Chrzaszcze Coleoptera, Biegaczowate Carabidae, Vol. XXIII, t. 3-4.-PWN. [In Polish.]

du Bus de Warnaffe, G. \& Lebrun, P. 2004: Effects of forest management on carabid beetles in Belgium: implications for biodiversity conservation. - Biological Conservation 118: 219-234.

Foster, D. R., Orwig, D. A. \& McLachlan, J. S. 1996: Ecological and conservation insights from reconstructive studies of temperate old-growth forests. - Trends in Ecology and Evolution 11: 419-424.

Guillemain, M., Loreau, M. \& Daufrense, T. 1997: Relationship between the regional distribution of carabid beetles (Coleoptera, Carabidae) and the abundance of their potential prey. - Acta Oecologia 18: 465-483.

Kimmins, J. P. 1997: Forest Ecology. A Foundation for Sustainable Management. Second Edition. - Prentice Hall. 598 pp.

Koivula, M. 2001: Carabid beetles (Coleoptera, Carabidae) in boreal managed forests - meso-scale ecological patterns in relation to modern forestry. - $\mathrm{PhD}$ thesis, University of Helsinki. 120 pp. 
Koivula, M. 2002: Alternative harvesting methods and boreal carabid beetles (Coleoptera, Carabidae). - Forest Ecology and Management 167: 103-121.

Koivula, M., Punttila, P., Haila, Y. \& Niemelä, J. 1999: Leaf litter and the small-scale distribution of carabid beetles (Coleoptera, Carabidae) in the boreal forest. Ecography 22: 424-435.

Koivula, M. \& Niemelä, J. 2003: Gap felling as a forest harvesting method in boreal forests: responses of carabid beetles (Coleoptera, Carabidae). - Ecography 26: 179-187.

Kotze, D. J. \& O'Hara, R. B. 2003: Species decline - but why? Explanations of carabid beetle (Coleoptera, $\mathrm{Ca}-$ rabidae) declines in Europe. - Oecologia 135: 138 148.

Krebs, C. J. 1999: Ecological methodology. Second edition. - Addison Wesley Longman. 620 pp.

Larsson S. G. 1939: Entwicklungstypen und Entwicklungszeiten der Dänischen Carabiden. - Entomologiske Meddelelser 20: 273-562.

Magura, T., Ködöböcz, V., Tóthmérész, B. 2001: Effects of habitat fragmentation on carabids in forest patches. - Journal of Biogeography 28: 129-138.

Niemelä, J., Langor, D. \& Spence, J. R. 1993: Effects of clear-cut harvesting on boreal ground-beetle assemblages (Coleoptera: Carabidae) in Western Canada. Conservation Biology 7: 551-561.

Niemelä, J., Haila, Y. \& Punttila, P. 1996: The importance of small-scale heterogeneity in boreal forests: variation in diversity in forest-floor invertebrates across the succession gradient. - Ecography 19: 352-368.

Pontégnie, M., du Bus de Warnaffe, G. \& Lebrun, P. 2005 : Impacts of silvicultural practices on the structure of hemi-edaphic macrofauna community. - Pedobiologia 49: 199-210.

Poole, A., Gromally, M. \& Skeffington, M. 2003: The flora and carabid fauna of a mature and regenerating semi-natural oak woodland in south-east Ireland. Forest Ecology and Management 177: 207-220.

Rackham, O. 1980: Ancient Woodland. - Arnold, London.

Ribera, I., Dolédec, S., Downie, I. S. \& Foster, G. N. 2001: Effect of land disturbance and stress on species traits of ground beetles assemblages. - Ecology 82: 1112 1129.

Sklodowski, J. 1995: Antropogenne przeobrażenia zespołów biegaczowatych (Col. Carabidae) w ekosystemach borów sosnowych Polski. [Anthropogenic changes in carabid assemblages (Col. Carabidae) in pine forest ecosystems In Poland.] — In: A. Szujecki et al. (eds.), Antropogeniczne przeobrażenia epigeicznej i glebowej entomofauny borów sosnowych: 17-174. Katedra Ochrony Lasu i Ekologii. Fundacja "Rozwój SGGW", Warszawa. [In Polish.]

Skłodowski, J. 1997: Interpretacja stanu środowiska leśnego za pomocą modelu SCP/SBO zgrupowan biegaczowatych (Col. Carabidae). Interpretation of state of environment by using SPC/MIB model of carabids assemblages. - In: Mazur, S. et al. (eds.),
Waloryzacja ekosystemów lesnych metodami zooindykacyjnymi. VI Sympozjum Ochrony Ekosystemów Lesnych. Jedlnia 2-3 grudnia 1996: 69-87. Fundacja Rozwój SGGW. [In Polish.]

Skłodowski, J. 1999: Movement of selected carabid species (Col. Carabidae) through a pine forest-fallow ecotone. - Folia Forestalia Polska Ser. A. 41: 5-23.

Skłodowski, J. 2002: System kolonizacji zrębu zupełnegoi przez biegaczowate oraz możliwości jego doskonalenia. System of colonization clear-cut area by carabid beetles and possibility of its improving Wydawnictwo SGGW, Warsaw Agricultural University Press. 134 pp. [In Polish with English summary.]

Skłodowski, J. 2003: Epigeic Carabid assemblages of the Białowieża Primeval Forest. - In: Bauer T. et al. (eds.), How to protect or What we know about Carabid Beetles. From knowledge to application - from Wijster (1969) to Tuczno (2001): 259-272. Warsaw Agricultural University Press.

Skłodowski, J. 2005: Intraspecific body size differentiation in Carabus assemblages in the Białowieża Primeval Forest, Poland. - In: Lövei G. L. \& Toft, S. (eds.), European Carabidology 2003. Proceedings of the $11^{\text {th }}$ European Carabidologist Meeting: 291-303. DIAS Report No. 114.

Spence, J. R., Langor, D. W., Niemelä, J., Carcamo, H. A. \& Currie, C. R. 1996: Northern forestry and carabids: The case for concern about old-growth species. - Annales Zoologici Fennici 33: 302-302.

StatSoft Inc. 1997: Statistica for Windows (Computer program manual). - Tulsa, OK, USA.

Szyszko, J. 1983: State of Carabidae (Col.) fauna in fresh pine forest and tentative valorisation of this environment. - Warsaw Agricultural University Press.

Szyszko J. 1990: Planning of prophylaxis in threatened pine forest biocenoses based on an analysis of the fauna of epigeic Carabidae. - Warsaw Agricultural University Press.

Szyszko, J. 2002: Carabids as an efficient indicator of the quality and functioning of forest ecosystems useful in forest management. - In: Szyszko, J. et al. (eds.), How to protect or What we know about Carabid Beetles. From knowledge to application - from Wijster (1969) to Tuczno (2001): 301-318. Warsaw Agricultural University Press. 378 pp.

Szujecki, A. 1971: The effect of clear-cutting upon the community of litter inhabiting Staphylinids (Col. Staphylinidae) in fresh pine forests. - Folia Forestalia Polska Ser. A. 18: 5-45.

Szujecki, A., Mazur, S., Perliński, S. \& Szyszko, J. 1983: The process of forest soil macrofauna formation after afforestation of farmland. — Warsaw Agricultural University Press.

Szujecki, A., Sławska, M., Skłodowski, J., Smoleński, M., Perliński, S., Mazur S., Lęgowski, D., Tracz, H., Sawoniewicz, J., Mokrzycki, T., Borowski, J., Rutkiewicz, A. \& Byk, A. 2001: Próba szacunkowej waloryzacji lasów Puszczy Białowieskiej metodą zooindykacyjna. - Wydawnictwo SGGW, Warsaw Agricultural University Press. 41 pp. [In Polish.] 
ter Braak, C.J.F. \& Smilauer, P. 1997: CANOCO for Windows v. 4.02. - Centre for Biometry Wageningen, The Netherlands.

Turin, H. 2000: De Nedrelandse loopkevers. Verspreiding en oecologie (Coleoptera: Carabidae). Nationaal Natuurhistorisch Museum Naturalis. - KNNV Uitgeverij. 662 pp. [In Dutch.]

Wesołowski, T. 1995: Value of Białowieża forest for the conservation of white-backed woodpecker Dendrocopos leucotos in Poland. - Biological Conservation 71: 69-75.
Wesołowski, T, 2005: Virtual conservation: how the European Union is turning a blind eye to its vanishing primeval forests. - Conservation Biology 19: 1349 1358.

Witkowski, Z. J. 2000: Restytucja owadów w Polsce w świetle teorii ekologicznej, zaleceń Unii Europejskiej i krajowych doświadczeń. [Recovery of insects in Poland in light of ecological theory, recommendation of European Union and local experience.] — Wiad. Entomol. 18 Suppl. 2: 251-273. [In Polish with English summary.] 
Appendix. Carabid beetles collected in primeval and anthropogenic habitats (see Table 1 for habitat abbreviations). Species characteristics: $r=$ relict, $b=$ brachypterous, and $h=$ hygrophilous. The subsequent columns (except "Other" and "Sum") show values for different habitats (for coding, see Table 1). The numbers refer to dominance indices exceeding $5 \%$; " 1 " is used when a dominance index was $<5 \%$; and " + " indicates that only a few specimens were found. Other $=$ catches of carabids in other anthropogenic variants (not included in the analysis).

MD5 MD15

Agonum assimile (Paykull, 1790)

A. dorsale (Pontoppidan, 1763)

A. fuliginosum (Duftschmid, 1812)

A. gracilis (Sturm, 1824)

A. livens (Gyllenhal, 1810)

A. micans (Nicolai, 1822)

A. obscurum (Herbst, 1784)

A. piceus (Linnaeus, 1758)

A. sexpunctatum (Linnaeus, 1758)

A. viduum (Panzer, 1797)

Amara aenea (De Geer, 1774)

A. apricaria (Paykull, 1790)

A. aulica (Panzer, 1797)

A. bifrons (Gyllenhal, 1810)

A. brunnea (Gyllenhal, 1810)

A. consularis (Duftschmid, 1812)

A. communis (Panzer, 1797)

A. eurynota (Panzer, 1797)

A. familaris (Duftschmid, 1812)

A. fulva (Müller, 1776)

A. Iunicollis Schiødte, 1837

A. majuscula Chaudoir, 1850

A. ovata (Fabricius, 1792)

A. plebeja (Gyllenhal, 1810)

A. tibialis (Paykull, 1798)

Anisodactylus binotatus (Fabricius, 1792)

Broscus cephalotes (Linnaeus, 1758)

Bembidion gilvipes Sturm, 1825

B. lampros (Herbst, 1784)

B. mannerheimi C. R. Sahlberg, 1827

B. nigricorne Gyllenhal, 1827

B. properans (Stephens, 1828)

B. pygmaeum (Fabricius, 1792)

B. quadrimaculatum (Linnaeus, 1761)

B. semipunctatum (Donovan, 1806)

Badister bullatus (Schrank, 1798)

B. dilitatus Chaudoir, 1837

B. drosiger (Duftschmid, 1812)

$B$. lacertosus Sturm, 1815

B. sodalis (Duftschmid, 1812)

B. unipustulatus Bonelli, 1813

Carabus arcensis Herbst, 1784

C. cancellatus Illiger, 1798

C. coriaceus Linnaeus, 1758

C. convexus Fabricius, 1775

C. glabratus Paykull, 1790

C. granulatus Linnaeus, 1758

C. hortensis Linnaeus, 1758

C. intricatus Linnaeus, 1761

C. nemoralis O. F. Müller, 1764

C. violaceus Linnaeus, 1758

\begin{tabular}{|c|c|c|c|c|c|c|c|c|c|c|c|c|c|}
\hline \multirow[t]{2}{*}{$\mathrm{r}, \mathrm{h}$} & 0 & 0 & + & + & 5.4 & 0 & 0 & 0 & 0 & 0 & + & 0 & \\
\hline & 0 & 0 & 0 & 0 & 0 & 0 & 0 & 0 & 0 & 0 & 0 & 0 & \\
\hline $\mathrm{h}$ & + & + & + & + & 10.1 & 0 & + & 0 & 0 & + & 0 & + & \\
\hline $\mathrm{h}$ & 0 & 0 & 0 & 0 & + & 0 & 0 & 0 & 0 & 0 & 0 & 0 & \\
\hline $\mathrm{h}$ & 0 & 0 & + & + & 1 & 0 & 0 & 0 & 0 & 0 & 0 & 0 & \\
\hline $\mathrm{h}$ & 0 & 0 & 0 & 0 & + & 0 & 0 & 0 & 0 & 0 & 0 & 0 & \\
\hline h & + & + & + & + & 9.2 & 0 & + & 1 & 0 & 0 & + & 0 & \\
\hline $\mathrm{h}$ & 0 & 0 & 0 & 0 & + & 0 & 0 & 0 & 0 & 0 & 0 & 0 & \\
\hline h & 0 & 0 & 0 & 0 & + & 0 & 0 & 0 & 0 & 0 & 0 & 0 & \\
\hline \multirow[t]{5}{*}{ h } & + & 0 & 0 & + & + & 0 & 0 & 0 & 0 & 0 & 0 & 0 & \\
\hline & 0 & 0 & + & 0 & 0 & 1 & 0 & 0 & 0 & 0 & 0 & 0 & \\
\hline & 0 & 0 & 0 & 0 & 0 & 0 & 0 & 0 & 0 & 0 & 0 & + & \\
\hline & 0 & 0 & 0 & 0 & 0 & 0 & 0 & 0 & 0 & 0 & 0 & 0 & \\
\hline & + & 0 & 0 & 0 & 0 & 0 & 0 & 0 & + & + & 0 & 0 & \\
\hline \multirow[t]{9}{*}{$r$} & + & + & + & + & + & 0 & + & 0 & 0 & 0 & + & + & \\
\hline & 0 & 0 & 0 & 0 & 0 & 0 & 0 & 0 & 0 & 0 & 0 & 0 & \\
\hline & 0 & 0 & + & + & 0 & + & + & 0 & 0 & 0 & 0 & + & \\
\hline & 0 & 0 & 0 & 0 & 0 & 0 & 0 & 0 & 0 & 0 & 0 & 0 & \\
\hline & 0 & 0 & 0 & 0 & 0 & 0 & 0 & 0 & 0 & 0 & 0 & + & \\
\hline & 0 & 0 & 0 & 0 & 0 & 0 & 0 & 0 & 0 & 0 & 0 & 0 & \\
\hline & 0 & 0 & 0 & + & 0 & + & + & 0 & + & 0 & 0 & 1 & \\
\hline & 0 & 0 & 0 & 0 & + & 0 & 0 & 0 & 0 & 0 & 0 & 0 & \\
\hline & 0 & 0 & 0 & 0 & 0 & 0 & 0 & 0 & 0 & 0 & 0 & 0 & \\
\hline \multirow[t]{2}{*}{ h } & 0 & + & + & 0 & 0 & 0 & 0 & 0 & + & 0 & 0 & + & \\
\hline & 0 & 0 & 0 & 0 & 0 & 0 & 0 & 0 & + & 0 & 0 & 0 & \\
\hline \multirow[t]{2}{*}{ h } & 0 & + & 0 & 0 & 0 & 0 & 0 & 0 & 0 & 0 & 0 & 0 & \\
\hline & 0 & 0 & 0 & 0 & 0 & 0 & 0 & 0 & 0 & 0 & 0 & + & \\
\hline \multirow[t]{2}{*}{ h } & 0 & 0 & 0 & + & 0 & 0 & 0 & 0 & 0 & 0 & 0 & 0 & \\
\hline & 0 & 0 & + & + & + & 0 & 0 & 0 & 0 & 0 & 0 & + & \\
\hline \multirow[t]{5}{*}{$h, b$} & 0 & + & 0 & 0 & 0 & 0 & 0 & 0 & 0 & 0 & 0 & 0 & \\
\hline & 0 & 0 & 0 & 0 & 0 & + & 0 & 0 & 0 & 0 & 0 & + & \\
\hline & 0 & 0 & 0 & + & 0 & 0 & 0 & 0 & 0 & 0 & 0 & 0 & \\
\hline & 0 & 0 & 0 & 0 & 0 & 0 & 0 & 0 & 0 & 0 & 0 & 0 & \\
\hline & 0 & 0 & 0 & 0 & 0 & 0 & 0 & 0 & 0 & 0 & 0 & 0 & \\
\hline \multirow[t]{2}{*}{ h } & 0 & 0 & 0 & 0 & 0 & 0 & 0 & 0 & 0 & 0 & 0 & 0 & \\
\hline & 0 & 0 & + & + & 0 & 0 & 0 & 0 & 0 & 0 & 0 & + & \\
\hline h & 0 & 0 & 0 & + & + & 0 & 0 & 0 & 0 & 0 & 0 & 0 & \\
\hline \multirow[t]{2}{*}{ h } & 0 & 0 & 0 & 0 & 0 & 0 & 0 & 0 & 0 & 0 & 0 & 0 & \\
\hline & 0 & 0 & + & + & + & 0 & 0 & 0 & 0 & 0 & + & 1 & \\
\hline$h, b$ & 0 & 0 & 0 & 0 & + & 0 & 0 & 0 & 0 & 0 & 0 & 0 & \\
\hline $\mathrm{h}$ & 0 & 0 & 0 & 0 & 0 & 0 & 0 & 0 & 1 & 0 & 0 & 0 & \\
\hline$b$ & 42.6 & 13.2 & 6.5 & 9.8 & 1 & 0 & + & + & 1 & 6.6 & 10.1 & 5.5 & \\
\hline$b$ & + & + & + & + & + & 1 & + & 1 & 1 & 1 & + & 1 & \\
\hline$b$ & 1 & 1 & + & + & + & 1 & + & 1 & 1 & 0 & 1 & 1 & \\
\hline$b$ & + & + & + & + & + & + & 0 & 0 & 0 & 1 & + & 1 & \\
\hline$r, b$ & 1 & 13.3 & 11.1 & 1 & 1 & + & 0 & 0 & 0 & 1 & + & 7.9 & 10 \\
\hline$h, b$ & 0 & + & + & + & 1 & + & 1 & 1 & 0 & 1 & 1 & 1 & \\
\hline$r, b$ & + & 43.3 & 46.8 & 19.9 & 6.2 & + & + & + & 7.2 & 1 & 1 & 1 & \\
\hline \multirow[t]{2}{*}{$r, b$} & 0 & + & + & + & 0 & 0 & 0 & 0 & 0 & 0 & 0 & 0 & \\
\hline & + & 1 & 1 & 1 & 1 & 1 & + & 8.4 & 0 & 1 & + & + & \\
\hline$r, b$ & 8.1 & 1 & + & + & + & 1 & + & + & 1 & + & 1 & 0 & \\
\hline
\end{tabular}


Calathus erratus (C. R. Sahlberg, 1827)

C. fuscipes (Goeze, 1777)

C. melanocephalus (Linnaeus, 1758)

C. micropterus (Duftschmid, 1812)

Clivina fossor (Herbst, 1784)

Calosoma inquisitor (Linnaeus, 1758)

Cychrus caraboides (Linnaeus, 1758)

Chlaeniellus nigricornis (Fabricius, 1787)

Cicindela sylvatica Linnaeus, 1758

Cymindis macularis Mannerheim

in Fischer von Waldheim, 1824

Dolichus halensis (Schaller, 1783)

Dromius agilis (Fabricius, 1787)

D. fenestratus (Fabricius, 1794)

D. schneideri Crotch, 1871

D. sigma (Rossi, 1790)

Dyschirius globosus (Herbst, 1783)

Elaphrus cupreus Duftschmid, 1812

Epaphius rivularis (Gyllenhal, 1810)

E. secalis (Paykull, 1790)

Harpalus affinis (Schrank, 1781)

H. anxius (Duftschmid, 1812)

H. fuliginosus (Panzer, 1809)

H. griseus (Panzer, 1797)

H. latus (Linnaeus, 1758)

H. luteicornis (Duftschmid, 1812)

H. neglectus Serville, 1821

H. picipennis (Duftschmid, 1812)

H. progrediens Schauberger, 1922

H. quadripunctatus Dejean, 1829

H. rubripes (Duftschmid, 1812)

H. rufipes (De Geer, 1774)

H. rufitarsis (Illiger, 1778)

$\begin{array}{rrrrrrrrrr} & + & 0 & + & + & 0 & 0 & + & 0 \\ & 0 & 0 & 0 & 0 & 0 & 0 & + & 0 & \\ & 0 & 0 & 0 & 0 & 0 & 5 & 38.7 & 21.3 & 15.5 \\ \mathrm{r}, \mathrm{b} & 1 & + & 1 & + & + & 0 & 1 & 17.1 & 0 \\ \mathrm{~h} & 0 & 0 & + & + & + & 0 & 0 & 0 \\ & 0 & + & 0 & + & 0 & 0 & 0 & 0 \\ \mathrm{~h}, \mathrm{~b} & 1 & 1 & 1 & 1 & 1 & 1 & 1 & + \\ \mathrm{h} & + & 0 & 0 & 0 & + & 0 & 0 & 0 \\ & + & 0 & 0 & 0 & 0 & 0 & 0 & 0\end{array}$

$\begin{array}{rrrrr}0 & + & 0 & + & 0 \\ 1 & 0 & 0 & 0 & 0 \\ 15.5 & 1 & 15.6 & 1 & 0 \\ 0 & 5.8 & 1 & 1 & 6.5 \\ 0 & + & 0 & 0 & 0 \\ 0 & + & + & 0 & 0 \\ 1 & 1 & 1 & 1 & 5.9 \\ 0 & 0 & 0 & + & 0 \\ 0 & 0 & 0 & 0 & 0\end{array}$

Harpalus signaticornis (Duftschmid, 1812)

H. smaragdinus (Duftschmid, 1812)

H. tardus (Panzer, 1796)

H. tenebrosus (Schauberger, 1929)

Lebia chlorocephala (Hoffmannsegg, 1803)

Leistus ferrugineus (Linnaeus, 1758)

L. piceus Froelich, 1979

L. rufescens (Fabricius, 1775)

Loricera pilicornis (Fabricius, 1775)

Licinus depressus (Paykull, 1790)

Masoreus wetterhalli (Linnaeus, 1767)

Miscodera arctica (Paykull, 1798)

Microlestes minutulus (Goeze, 1777)

Nebria brevicollis (Fabricius, 1792)

Notiophilus aesthuans (Motschulsky, 1864)

N. aquaticus (Linnaeus, 1758)

N. biguttatus (Fabricius, 1799)

N. germinyi Fauvel in Grenier, 1863

N. palustris (Duftschmid, 1812)

Oodes helopioides (Fabricius, 1792)

Ophonus puncticollis (Paykull, 1798)

Panagaeus bipustulatus (Fabricius, 1775)

P. cruxmajor (Linnaeus, 1758)

Patrobus atrorufus (Strøm, 1768)

Pterostichus aethiops (Panzer, 1797)

$P$. anthracinus (Illiger, 1798)

$P$. cupreus (Linnaeus, 1758)

\begin{tabular}{|c|c|c|c|c|c|c|c|c|c|c|c|}
\hline & 0 & 0 & 0 & 0 & 0 & 0 & 0 & 0 & 0 & 0 & c \\
\hline & 0 & 0 & 0 & 0 & 0 & 0 & 0 & 0 & 0 & 0 & 0 \\
\hline & 0 & + & 0 & + & 0 & 0 & 0 & 0 & 0 & 0 & c \\
\hline & 0 & 0 & 0 & 0 & 0 & 0 & 0 & 0 & 0 & 0 & c \\
\hline & 0 & 0 & 0 & 0 & 0 & 0 & 0 & 0 & 0 & 0 & c \\
\hline \multirow[t]{2}{*}{$\mathrm{h}$} & 0 & 0 & 0 & 0 & 0 & 0 & 0 & 0 & 0 & 0 & + \\
\hline & 0 & + & + & 1 & 0 & + & 0 & 0 & + & 0 & + \\
\hline h & + & + & 0 & + & 0 & 0 & 0 & 0 & 0 & 0 & c \\
\hline$h, b$ & 0 & 0 & 0 & 0 & + & + & 0 & 0 & 0 & 0 & c \\
\hline \multirow[t]{10}{*}{$b$} & + & 1 & 1 & 1 & 12.5 & 8.4 & 9.4 & 1 & 12.4 & 1 & 12.1 \\
\hline & 0 & 0 & 0 & 0 & 0 & 0 & 0 & 0 & 0 & 0 & c \\
\hline & 0 & 0 & 0 & 0 & 0 & 0 & 0 & 0 & 0 & 0 & c \\
\hline & 0 & + & + & 0 & 0 & 0 & 0 & 0 & + & 0 & c \\
\hline & 0 & + & 0 & 0 & 0 & 0 & 0 & 0 & + & 0 & c \\
\hline & + & + & + & + & + & + & 0 & 1 & + & + & 1 \\
\hline & 0 & 0 & 0 & 0 & 0 & 0 & 0 & 0 & 0 & 0 & c \\
\hline & 0 & 0 & 0 & 0 & 0 & 0 & 0 & 0 & 0 & 0 & c \\
\hline & 0 & 0 & 0 & 0 & 0 & 0 & 0 & 0 & 0 & 0 & c \\
\hline & 0 & 0 & 0 & 0 & 0 & 0 & 0 & 0 & 0 & 0 & $c$ \\
\hline \multirow[t]{4}{*}{$r$} & + & + & + & + & 1 & + & 1 & 1 & + & 1 & 5.1 \\
\hline & 0 & 0 & 0 & 0 & 0 & 0 & 0 & + & 0 & 0 & c \\
\hline & 0 & + & + & 0 & 1 & + & + & 7.7 & + & + & + \\
\hline & 0 & + & 0 & 0 & 0 & 0 & 0 & 1 & + & 0 & c \\
\hline \multirow[t]{4}{*}{0} & 0 & 0 & 0 & + & 0 & 0 & 0 & 0 & 0 & 0 & + \\
\hline & 0 & 0 & 0 & 0 & 0 & 0 & 0 & 0 & 0 & 0 & c \\
\hline & 0 & 0 & 0 & 0 & 0 & 0 & + & 1 & 0 & 0 & c \\
\hline & 0 & 0 & 0 & 0 & 0 & 0 & 0 & 0 & 0 & + & c \\
\hline & 0 & 0 & 0 & 0 & 0 & 0 & 0 & 0 & 0 & 0 & c \\
\hline $\mathrm{h}$ & 0 & 0 & 0 & + & + & + & 0 & 0 & 0 & + & c \\
\hline$r, b$ & 0 & + & + & + & 0 & 0 & 0 & 0 & + & 0 & c \\
\hline \multirow[t]{2}{*}{$h$} & + & + & 0 & + & 0 & 0 & 0 & 0 & 0 & 0 & + \\
\hline & + & + & + & 1 & 0 & 0 & 0 & 0 & 0 & 0 & c \\
\hline \multirow[t]{5}{*}{$b$} & 0 & 0 & 0 & 0 & 0 & 0 & 0 & 0 & 0 & 0 & c \\
\hline & 0 & 0 & 0 & + & 0 & 0 & 0 & 1 & 0 & 0 & $c$ \\
\hline & 0 & 0 & 0 & 0 & 0 & 0 & 0 & 1 & 0 & 0 & c \\
\hline & 0 & 0 & 0 & 0 & 0 & 0 & 0 & 0 & 0 & 0 & + \\
\hline & 0 & + & 1 & 6.1 & 0 & 0 & 0 & 0 & 0 & 0 & c \\
\hline \multirow[t]{5}{*}{0} & 0 & + & + & 0 & 0 & 0 & 0 & 0 & 0 & 0 & c \\
\hline & 0 & + & 0 & 0 & 0 & 0 & 0 & 0 & 0 & 0 & c \\
\hline & + & + & + & 0 & 0 & 0 & + & 0 & 0 & + & c \\
\hline & + & + & 0 & 0 & 0 & 0 & + & 1 & + & 0 & + \\
\hline & + & + & + & 0 & 0 & 0 & 0 & 0 & 0 & 0 & 1 \\
\hline \multirow[t]{2}{*}{$\mathrm{h}$} & 0 & 0 & 0 & + & 0 & 0 & 0 & 0 & 0 & 0 & c \\
\hline & 0 & 0 & 0 & 0 & 0 & 0 & 0 & 0 & 0 & 0 & c \\
\hline 0 & 0 & 0 & 0 & 0 & 0 & 0 & 0 & 0 & 0 & 0 & c \\
\hline $\mathrm{h}$ & 0 & 0 & 0 & + & + & 0 & 0 & 0 & 0 & 0 & c \\
\hline$h, b$ & + & + & + & 1 & 0 & 0 & 0 & 0 & 0 & 0 & c \\
\hline b & + & 0 & 1 & 1 & 2.5 & 1 & + & 0 & + & $t$ & + \\
\hline \multirow[t]{2}{*}{$\mathrm{h}$} & + & 0 & + & 1 & 0 & 0 & 0 & 0 & 0 & 0 & c \\
\hline & 0 & 0 & + & 0 & 0 & 0 & 0 & + & 0 & 0 & \\
\hline
\end{tabular}


P. diligens (Sturm, 1824)

P. melanarius (Illiger, 1798)

P. minor (Gyllenhal, 1827)

P. niger (Schaller, 1783)

P. nigrita (Paykull, 1790)

P. oblongopunctatus (Fabricius, 1787)

P. quadrifoveolatus Letzner, 1852

$P$. strenuus (Panzer, 1797)

$P$. vernalis (Panzer, 1796)

Poecilus versicolor (Linnaeus, 1758)

P. punctulatus (Schaller, 1783)

$P$. lepidus (Leske, 1787)

Synuchus nivialis (Illiger, 1798)

Stomis pumicatus (Panzer, 1796)

Syntomus foveatus (Fourcroy, 1785)

S. truncatellus (Linnaeus, 1761)

T. quadristriatus (Schrank, 1781)

Trichocellus placidius (Gyllenhal, 1827)

Microlestes maurus (Sturm, 1827) h

h

h $10 \quad 6.7$

h

710

10.2

$\begin{array}{ll}0 & + \\ 0 & 0\end{array}$

$+\quad+$

b

b

Total

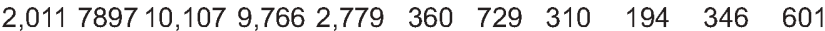

543758

Appendix. Continued.

Agonum assimile (Paykull, 1790)

A. dorsale (Pontoppidan, 1763)

A. fuliginosum (Duftschmid, 1812)

A. gracilis (Sturm, 1824)

A. livens (Gyllenhal, 1810)

A. micans (Nicolai, 1822)

A. obscurum (Herbst, 1784)

A. piceus (Linnaeus, 1758)

A. sexpunctatum (Linnaeus, 1758)

A. viduum (Panzer, 1797)

Amara aenea (De Geer, 1774)

A. apricaria (Paykull, 1790)

A. aulica (Panzer, 1797)

A. bifrons (Gyllenhal, 1810)

A. brunnea (Gyllenhal, 1810)

A. consularis (Duftschmid, 1812)

A. communis (Panzer, 1797)

A. eurynota (Panzer, 1797)

A. familaris (Duftschmid, 1812)

A. fulva (Müller, 1776)

A. Iunicollis Schiødte, 1837

A. majuscula Chaudoir, 1850

A. ovata (Fabricius, 1792)

A. plebeja (Gyllenhal, 1810)

A. tibialis (Paykull, 1798)

Anisodactylus binotatus (Fabricius, 1792)

Broscus cephalotes (Linnaeus, 1758)

Bembidion gilvipes Sturm, 1825

B. lampros (Herbst, 1784)

B. mannerheimi C. R. Sahlberg, 1827

B. nigricorne Gyllenhal, 1827

\begin{tabular}{|c|c|c|c|c|c|c|c|c|c|c|c|c|c|}
\hline 0 & + & 1 & 1 & 0 & 0 & 0 & + & 0 & 0 & 0 & + & 52 & 274 \\
\hline 0 & 0 & + & 0 & 0 & 0 & 0 & 0 & 0 & 0 & 0 & 0 & 111 & 112 \\
\hline+ & 12.7 & 1 & 15.8 & + & + & 0 & + & 0 & 0 & 0 & + & 10 & 520 \\
\hline 0 & 0 & 0 & 0 & 0 & 0 & 0 & 0 & 0 & 0 & 0 & 0 & 1 & 8 \\
\hline 0 & 1 & 1 & 14.9 & 0 & 0 & 0 & + & 0 & 0 & 0 & 0 & 0 & 206 \\
\hline 0 & 0 & 0 & 0 & 0 & 0 & 0 & 0 & 0 & 0 & 0 & 0 & 0 & 3 \\
\hline+ & 1 & 12.1 & 11.2 & 0 & 0 & 0 & 0 & 0 & + & + & 0 & 11 & 455 \\
\hline+ & 4.1 & + & 5.6 & 0 & 0 & 0 & + & 0 & 0 & 0 & 0 & 1 & 60 \\
\hline 0 & + & 0 & 0 & 0 & 0 & 0 & 0 & 0 & 0 & 0 & 0 & 0 & 3 \\
\hline 0 & 1 & + & 0 & 0 & 0 & 0 & 0 & 0 & 0 & 0 & 0 & 0 & 42 \\
\hline 0 & 0 & 0 & 1 & 0 & 0 & 0 & 0 & 0 & 0 & 0 & 0 & 112 & 132 \\
\hline 0 & 0 & 0 & 0 & 0 & 0 & 0 & 0 & 0 & 0 & 0 & 0 & 10 & 11 \\
\hline 0 & 0 & 0 & 0 & 0 & 0 & 0 & 0 & 0 & 0 & 0 & 0 & 13 & 13 \\
\hline 0 & 0 & 0 & 1 & 0 & 0 & 0 & 0 & 0 & 0 & 0 & 0 & 75 & 83 \\
\hline+ & 0 & 0 & 0 & 0 & + & 0 & 0 & + & 0 & + & 1 & 60 & 181 \\
\hline 0 & 0 & 0 & 0 & 0 & 0 & 0 & 0 & 0 & 0 & 0 & 0 & 121 & 121 \\
\hline 0 & + & + & 0 & 0 & 0 & 0 & 0 & 0 & 0 & + & 0 & 97 & 111 \\
\hline 0 & 0 & 0 & 0 & 0 & 0 & 0 & 0 & 0 & 0 & 0 & 0 & 9 & 9 \\
\hline 0 & 0 & 0 & 0 & 0 & 0 & 0 & 0 & 0 & 0 & 0 & 0 & 0 & 2 \\
\hline 0 & 0 & 0 & + & 0 & 0 & 0 & 0 & 0 & 0 & 0 & 0 & 12 & 13 \\
\hline 0 & 0 & 0 & 1 & 0 & 0 & 0 & 0 & 0 & 0 & 0 & + & 80 & 107 \\
\hline 0 & 0 & 0 & 0 & 0 & 0 & 0 & 0 & 0 & 0 & 0 & 0 & 1 & 2 \\
\hline 0 & 0 & 0 & 0 & 0 & 0 & 0 & 0 & 0 & 0 & 0 & 0 & 8 & 8 \\
\hline 0 & 0 & 0 & 1 & 0 & 0 & 0 & 0 & 0 & 0 & 0 & 0 & 32 & 59 \\
\hline 0 & 0 & 0 & 0 & 0 & 0 & 0 & 0 & 0 & 0 & 0 & 0 & 68 & 69 \\
\hline 0 & 0 & 0 & 0 & 0 & 0 & 0 & 0 & 0 & 0 & 0 & 0 & 46 & 47 \\
\hline 0 & 0 & 0 & 0 & 0 & 0 & 0 & 0 & 0 & 0 & 0 & 0 & 81 & 85 \\
\hline 0 & 0 & 0 & 0 & 0 & 0 & 0 & 0 & 0 & 0 & 0 & 0 & 0 & 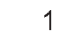 \\
\hline 0 & 0 & 0 & + & 0 & 0 & + & 0 & 0 & 0 & 0 & 0 & 24 & 32 \\
\hline+ & 0 & 0 & 0 & 0 & 0 & 0 & 0 & 0 & 0 & 0 & 0 & 0 & 3 \\
\hline+ & 0 & 0 & 0 & 0 & 0 & 0 & 0 & 0 & 0 & 0 & 0 & 8 & 12 \\
\hline
\end{tabular}


B. properans (Stephens, 1828)

B. pygmaeum (Fabricius, 1792)

B. quadrimaculatum (Linnaeus, 1761)

B. semipunctatum (Donovan, 1806)

Badister bullatus (Schrank, 1798)

B. dilitatus Chaudoir, 1837

B. drosiger (Duftschmid, 1812)

B. lacertosus Sturm, 1815

B. sodalis (Duftschmid, 1812)

B. unipustulatus Bonelli, 1813

Carabus arcensis Herbst, 1784

C. cancellatus Illiger, 1798

C. coriaceus Linnaeus, 1758

C. convexus Fabricius, 1775

C. glabratus Paykull, 1790

C. granulatus Linnaeus, 1758

C. hortensis Linnaeus, 1758

C. intricatus Linnaeus, 1761

C. nemoralis O. F. Müller, 1764

C. violaceus Linnaeus, 1758

Calathus erratus (C. R. Sahlberg, 1827)

C. fuscipes (Goeze, 1777)

C. melanocephalus (Linnaeus, 1758)

C. micropterus (Duftschmid, 1812)

Clivina fossor (Herbst, 1784)

Calosoma inquisitor (Linnaeus, 1758)

Cychrus caraboides (Linnaeus, 1758)

Chlaeniellus nigricornis (Fabricius, 1787)

Cicindela sylvatica Linnaeus, 1758

Cymindis macularis Mannerheim

in Fischer von Waldheim, 1824

Dolichus halensis (Schaller, 1783)

Dromius agilis (Fabricius, 1787)

D. fenestratus (Fabricius, 1794)

D. schneideri Crotch, 1871

D. sigma (Rossi, 1790)

Dyschirius globosus (Herbst, 1783)

Elaphrus cupreus Duftschmid, 1812

Epaphius rivularis (Gyllenhal, 1810)

E. secalis (Paykull, 1790)

Harpalus affinis (Schrank, 1781)

H. anxius (Duftschmid, 1812)

$H$. fuliginosus (Panzer, 1809)

H. griseus (Panzer, 1797)

H. latus (Linnaeus, 1758)

H. luteicornis (Duftschmid, 1812)

H. neglectus Serville, 1821

H. picipennis (Duftschmid, 1812)

H. progrediens Schauberger, 1922

H. quadripunctatus Dejean, 1829

H. rubripes (Duftschmid, 1812)

H. rufipes (De Geer, 1774)

H. rufitarsis (Illiger, 1778)

Harpalus signaticornis (Duftschmid, 1812)

H. smaragdinus (Duftschmid, 1812)

H. tardus (Panzer, 1796)

H. tenebrosus (Schauberger, 1929)

Lebia chlorocephala (Hoffmannsegg, 1803)

Leistus ferrugineus (Linnaeus, 1758)

L. piceus Froelich, 1979

\begin{tabular}{|c|c|c|c|c|c|c|c|c|c|c|c|c|c|}
\hline 0 & 0 & 0 & 0 & 0 & 0 & 0 & 0 & 0 & 0 & 0 & 0 & 17 & 18 \\
\hline 0 & 0 & 0 & 0 & 0 & 0 & 0 & 0 & 0 & 0 & 0 & 0 & 2 & 2 \\
\hline 0 & 0 & 0 & 0 & 0 & 0 & 0 & 0 & 0 & 0 & 0 & 0 & 5 & 5 \\
\hline 0 & 0 & 0 & 0 & 0 & 0 & 0 & 0 & 0 & 0 & 0 & 0 & 0 & \\
\hline 0 & + & + & 0 & 0 & 0 & 0 & 0 & 0 & + & 0 & 0 & 15 & 32 \\
\hline 0 & + & + & 0 & 0 & 0 & 0 & 0 & 0 & 0 & 0 & 0 & 1 & 16 \\
\hline 0 & + & 1 & 0 & 0 & 0 & 0 & 0 & + & + & 0 & + & 63 & 82 \\
\hline+ & + & + & 0 & + & 0 & 0 & + & 0 & + & + & 0 & 17 & 72 \\
\hline 0 & 0 & 0 & 0 & 0 & 0 & 0 & 0 & + & 0 & 0 & + & 4 & 11 \\
\hline 0 & 0 & 0 & + & 0 & 0 & 0 & 0 & 0 & 0 & 0 & 0 & 1 & \\
\hline 9 & 1 & 0 & + & 16.3 & 5.4 & 10.9 & 9.1 & + & + & 13.4 & + & 84 & 3,980 \\
\hline+ & 0 & + & 0 & 0 & + & 0 & 13.9 & 1 & 1 & + & + & 167 & 637 \\
\hline 1 & + & 0 & 0 & 1 & + & + & + & + & + & + & 1 & 30 & 447 \\
\hline+ & + & + & 0 & 0 & + & 0 & + & + & 13.2 & 0 & 1 & 75 & 431 \\
\hline 15.8 & + & 1 & + & 1 & 1 & 1 & + & + & 1 & + & 1 & 61 & 2,199 \\
\hline+ & 8.6 & + & 1 & 0 & 1 & 0 & 5.1 & 7 & 14.1 & + & 1 & 531 & 1,363 \\
\hline 28.2 & 1 & 1 & 0 & 6.4 & 10.0 & 9 & 11.2 & 5 & 1 & 1 & 8.9 & 1,004 & 11,907 \\
\hline 0 & 0 & 0 & 0 & 0 & 0 & 0 & 0 & 0 & 0 & 0 & 0 & 0 & 24 \\
\hline 1 & + & + & 0 & + & + & + & 6.7 & + & 1 & 6.4 & + & 224 & 1,401 \\
\hline+ & + & 0 & 0 & + & 1 & 1 & + & 0 & 0 & + & 0 & 279 & 827 \\
\hline 0 & 0 & 0 & 5.3 & 0 & 0 & 0 & + & 0 & 0 & 0 & 0 & 207 & 234 \\
\hline 0 & 0 & 0 & 1 & 0 & 0 & 0 & 0 & 0 & 0 & 0 & 0 & 174 & 189 \\
\hline+ & 0 & + & 1 & 0 & + & 0 & + & 1 & + & + & + & 299 & 885 \\
\hline 1 & + & 0 & 0 & + & + & + & + & 0 & 0 & + & 0 & 6 & 772 \\
\hline 0 & 0 & 0 & 0 & + & 0 & 0 & 0 & 0 & 0 & 0 & 0 & 28 & 35 \\
\hline 0 & 0 & 0 & 0 & 0 & + & 0 & + & + & + & + & + & 53 & 88 \\
\hline 1 & 1 & + & 0 & 5.8 & 5.4 & 1 & 1 & + & 1 & 1 & 1 & 337 & 1,380 \\
\hline 0 & 0 & 0 & 0 & 0 & 0 & 0 & 0 & 0 & 0 & 0 & 0 & 0 & \\
\hline 0 & 0 & 0 & 0 & 0 & 0 & 0 & 0 & 0 & 0 & 0 & 0 & 0 & \\
\hline
\end{tabular}

$\begin{array}{rrr}0 & 1 & 1 \\ 0 & 19 & 19 \\ 0 & 1 & 3 \\ 0 & 0 & 1 \\ 0 & 0 & 2 \\ 0 & 0 & 1 \\ 0 & 1 & 42 \\ 0 & 0 & 12 \\ 0 & 7 & 39 \\ 1 & 547 & 1,471 \\ 0 & 141 & 141 \\ 0 & 1 & 1 \\ 0 & 6 & 18 \\ + & 196 & 204 \\ + & 96 & 351 \\ 0 & 1 & 1 \\ 0 & 1 & 1 \\ 0 & 12 & 12 \\ 0 & 1 & 1 \\ 1 & 113 & 709 \\ 0 & 78 & 83 \\ + & 2,332 & 2,401 \\ 0 & 28 & 41 \\ 0 & 68 & 72 \\ 0 & 3 & 3 \\ 0 & 59 & 72 \\ 0 & 2 & 3 \\ 0 & 1 & 1 \\ 0 & 0 & 8 \\ + & 0 & 21\end{array}$ 
L. rufescens (Fabricius, 1775)

Loricera pilicornis (Fabricius, 1775)

Licinus depressus (Paykull, 1790)

Masoreus wetterhalli (Linnaeus, 1767)

Miscodera arctica (Paykull, 1798)

Microlestes minutulus (Goeze, 1777)

Nebria brevicollis (Fabricius, 1792)

Notiophilus aesthuans (Motschulsky, 1864)

N. aquaticus (Linnaeus, 1758)

N. biguttatus (Fabricius, 1799)

N. germinyi Fauvel in Grenier, 1863

N. palustris (Duftschmid, 1812)

Oodes helopioides (Fabricius, 1792)

Ophonus puncticollis (Paykull, 1798)

Panagaeus bipustulatus (Fabricius, 1775)

P. cruxmajor (Linnaeus, 1758)

Patrobus atrorufus (Strøm, 1768)

$P$. anthracinus (Illiger, 1798)

$P$. cupreus (Linnaeus, 1758)

P. diligens (Sturm, 1824)

$P$. melanarius (Illiger, 1798)

P. minor (Gyllenhal, 1827)

P. niger (Schaller, 1783)

P. nigrita (Paykull, 1790)

P. oblongopunctatus (Fabricius, 1787)

$P$. quadrifoveolatus Letzner, 1852

P. strenuus (Panzer, 1797)

$P$. vernalis (Panzer, 1796)

Poecilus versicolor (Linnaeus, 1758)

P. punctulatus (Schaller, 1783)

$P$. lepidus (Leske, 1787)

Synuchus nivialis (Illiger, 1798)

Stomis pumicatus (Panzer, 1796)

Syntomus foveatus (Fourcroy, 1785)

S. truncatellus (Linnaeus, 1761)

T. quadristriatus (Schrank, 1781)

Trichocellus placidius (Gyllenhal, 1827)

Microlestes maurus (Sturm, 1827)
Pterostichus aethiops (Panzer, 1797)

\begin{tabular}{|c|c|c|c|c|c|c|c|c|c|c|c|c|c|}
\hline 0 & 0 & + & 0 & 0 & 0 & 0 & 0 & 0 & 0 & 0 & 0 & 0 & 12 \\
\hline 0 & + & + & + & 0 & 0 & 0 & 0 & 0 & 0 & 0 & 0 & 5 & 76 \\
\hline 0 & 0 & 0 & 0 & 0 & 0 & 0 & 0 & 0 & 0 & 0 & 0 & 4 & \\
\hline 0 & 0 & + & + & 0 & 0 & 0 & 0 & 0 & 0 & 0 & 0 & 5 & \\
\hline 0 & 0 & 0 & 0 & 0 & 0 & 0 & 0 & 0 & 0 & 0 & 0 & 2 & \\
\hline+ & 0 & 0 & 0 & 0 & 0 & 0 & 0 & 0 & 0 & 0 & 0 & 1 & \\
\hline 0 & 0 & 0 & 0 & 0 & 0 & 0 & + & 0 & + & + & + & 6 & 507 \\
\hline 0 & 0 & 0 & 0 & 0 & + & 0 & 0 & 0 & 0 & 0 & 0 & 7 & \\
\hline 0 & 0 & 0 & 0 & 0 & 0 & 0 & 0 & 0 & 0 & 0 & + & 1 & \\
\hline 0 & 0 & 0 & 0 & 0 & + & 0 & + & 0 & 0 & 0 & 0 & 43 & \\
\hline+ & + & + & 0 & 0 & 0 & 0 & + & 0 & + & + & 0 & 29 & \\
\hline+ & 0 & 0 & 0 & 0 & 0 & 0 & 0 & 0 & 0 & 0 & 0 & 2 & \\
\hline 0 & 1 & 0 & + & 0 & 0 & 0 & 0 & 0 & 0 & 0 & 0 & 0 & \\
\hline 0 & 0 & 0 & 0 & 0 & 0 & 0 & 0 & 0 & 0 & 0 & 0 & 1 & \\
\hline 0 & 0 & 0 & 0 & 0 & 0 & 0 & 0 & 0 & 0 & 0 & 0 & 4 & \\
\hline 0 & 0 & + & 0 & 0 & 0 & 0 & 0 & 0 & 0 & 0 & 0 & 10 & \\
\hline 0 & 1 & 5.3 & 1 & 0 & + & 0 & + & 0 & 0 & 0 & 1 & 2 & 27 \\
\hline 0 & 0 & + & 0 & 0 & + & 0 & + & 0 & 1 & 1 & 1 & 17 & 328 \\
\hline 0 & 0 & 5.3 & 0 & 0 & + & 0 & 0 & 0 & 0 & + & + & 136 & 28 \\
\hline+ & 0 & 0 & 0 & 0 & 0 & 0 & 0 & 0 & 0 & 0 & + & 56 & \\
\hline+ & 1 & + & + & + & + & 0 & + & + & + & + & + & 25 & 13 \\
\hline+ & 11.4 & 8.2 & 0 & 5.2 & 1 & 0 & 9.3 & 6.1 & 6.7 & 23.0 & 25.4 & 966 & 3,567 \\
\hline 0 & 1 & 1 & 1 & 0 & 0 & 0 & 0 & 0 & + & 0 & 0 & 1 & \\
\hline & 30.9 & 22.4 & 6.2 & 43.7 & 46 & 43.8 & 12.2 & 27.5 & 24.9 & 33.0 & 17.1 & 1,665 & 9,625 \\
\hline 0 & 0 & 1 & + & 0 & + & 0 & 0 & 0 & 0 & 0 & 0 & 8 & 10 \\
\hline & 1 & 1 & + & 14.1 & 13.8 & 17.9 & 13.6 & 34.2 & 15.1 & 18.5 & 19.7 & 2,1531 & 12,22 \\
\hline 0 & 0 & 0 & 0 & 0 & 0 & 0 & 0 & 0 & 0 & 0 & 0 & 10 & \\
\hline+ & 1 & + & + & 0 & + & 0 & 0 & 0 & 0 & 0 & 0 & 15 & 13 \\
\hline 0 & + & 0 & 0 & 0 & 0 & 0 & 0 & 0 & 0 & 0 & 0 & 9 & \\
\hline+ & + & 1 & 0 & 1 & 1 & 1 & 1 & 1 & 1 & 1 & 1 & 905 & 1364 \\
\hline 0 & 0 & 0 & 0 & 0 & 0 & 0 & 0 & 0 & 0 & 0 & 0 & 16 & \\
\hline 0 & 0 & 0 & + & 0 & 0 & 0 & 0 & 0 & 0 & 0 & 0 & 253 & 327 \\
\hline 0 & 0 & + & + & 0 & 0 & + & 0 & 0 & 0 & 0 & 0 & 38 & \\
\hline 0 & + & 1 & + & 0 & 0 & 0 & + & 0 & + & + & + & 13 & \\
\hline 0 & 0 & 0 & 0 & 0 & 0 & 0 & 0 & 0 & 0 & 0 & 0 & 2 & \\
\hline 0 & 0 & 0 & 0 & 0 & 0 & 0 & 0 & 0 & 0 & 0 & 0 & 6 & \\
\hline+ & 0 & 0 & 0 & 0 & 0 & 0 & 0 & 0 & 0 & 0 & 0 & 3 & \\
\hline 0 & 0 & 0 & 0 & 0 & 0 & 0 & 0 & 0 & 0 & 0 & 0 & 0 & \\
\hline 0 & 0 & 0 & 0 & 0 & 0 & 0 & 0 & 0 & 0 & 0 & 0 & 0 & \\
\hline
\end{tabular}

Total

$1,229 \quad 676 \quad 588$ 